\title{
Financial Development, Savings and Economic Growth: Evidence from Bahrain Using VAR
}

\author{
Mohammed Ziaur Rehman ${ }^{1}$, Nasir Ali ${ }^{1} \&$ Najeeb Muhammad Nasir ${ }^{1}$ \\ ${ }^{1}$ Department of Finance, King Saud University, Riyadh, Saudi Arabia \\ Correspondence: Mohammed Ziaur Rehman, Assistant Professor, Department of Finance, King Saud University, \\ Riyadh, Saudi Arabia. E-mail: ziacommerce@gmail.com
}

Received: February 28, 2015

Accepted: March 31, 2015

Online Published: April 11, 2015

doi:10.5430/ijfr.v6n2p112

URL: http://dx.doi.org/10.5430/ijfr.v6n2p112

\begin{abstract}
This research paper investigates the linkage between the financial development and the economic growth in Bahrain during the period 1981 to 2013. The motivation for kicking off on the Bahrain economy is attributed on account of paradigm shift manifested in moving from hydrocarbons purveyor to being in the financial services and industrial hub. Given the limiting factor embedded with the bivariate causality structure, the paper encompasses savings as an intermittent variable. The paper makes an earnest investigation to gauge the long run and short run relationship among financial development, savings and the economic growth. Time series data are taken for a time span of 33 years (1981- 2013). Data are culled from the World Bank Database. Financial Development measured by M2(broad money)/ GDP is represented by F, Economic growth measured by GDP per capita is represented by Y and Savings measured by Domestic Savings/GDP is represented by S. No long term co-integration is found among the variables under consideration as represented by Johansen test. Through the employment of multiple econometrics tools under Vector Auto Regression (VAR) framework, it is unearthed that the empirical evidence supports neither the supply leading hypothesis nor the demand -following hypothesis for the Bahrain. While savings and economic growth have bi-directional causality at $10 \%$ level of significance. In responding to inexplicit results between the purported variables, the current study recommends that more wide ranges of reforms in the financial services are entailed, so as to escalate further the economic growth in the Bahrain economy.
\end{abstract}

Keywords: Bahrain, financial development, economic growth, savings, VAR

\section{Introduction}

In spite of the voluminous literature conducted on the arena of financial development and economic growth, there are difference in opinions pertaining to the direction and nature of the linkages on the purported theme. The gist of galore studies exhibits conflicting findings on the linkage between the development of a country's financial system and the scale \& pace of economic growth. Financial development is gauged by the ingredients, namely, size, depth, access, the efficiency and stability of a financial system. Financial milieu, per se, encompasses the markets, intermediaries, range of assets, institutions and regulations. Financial Structure and Development by Raymond W. Goldsmith's (1969) provided the fitting pedestal in igniting the economists to delve and unfold theoretical and empirical documentations associating with economic and financial development.

In this very vein, the current paper makes an earnest endeavor to report the relationship between financial development and economic growth on the landscape of Bahrain economy. The rationale of embarking upon the stipulated theme is on account of paucity of studies on the Bahrain economy. In response to the acknowledging of depletable oil reserves, Bahrain embarked in early eighties on an enterprising venture by redefining its future economic strategic directions. Bahrain was one of the leading GCC countries in moving from hydrocarbons exports to being in the financial services and industrial hub. Of late, Bahrain has established itself as one of the matured financial hub in the GCC region. Bahrain has metamorphosed from being exclusively contingent on oil resources to the fostering and developing of multifarious sectors of the economy. Banking and financial services have unfolded as an instrumental sector of the Bahrain economy. Rules and regulations in line with the global best practices have provided fitting pedestal for the multinational companies to make a beeline on the landscape of Bahrain economy. The unfolding of Bahrain as central financial destination in Middle East is on account of the robust financial frameworks that are in sync with the international financial yardsticks. As per the latest international economic 
reports, a substantial exhibition from the non-oil industries shall propel economic growth in Bahrain to exceed both the regional and global averages. Real GDP growth will reach 3.8 per cent in 2015 and 2016, compared to an annual average of 3.6 per cent between 2009 and 2013. The return to profit of government investment fund Mumtalakat and the strengthening of the domestic banking sector manifest unwavering economic prosperity in Bahrain. The retail banking in the kingdom remained untouched from the global economic crisis. In line with the international requirements, the banking watchdog is fortifying the sector by concentrating on the new Basel norms, promoting the corporate governance norms and safeguarding the consumer interests. With the revamping of the Bahrain Bourse in offing, it shall drive to greater speed and flexibility in the financial system. Initial public offerings shall get accelerated along with better trading rules and regulations. Following the Bahrain Economic Vision 2030, the government has made earnest endeavor to promote the private sector as the cardinal role player to augment growth in the economy. Bahrain shall sanguinely map out the economy's growth in expanding its economy and establishing an investor-friendly milieu, which shall lead to the further consolidation and diversification of the industries in the country. The rest of the paper is organized as follows: Section 2 provides extant literature on the purported theme. Section 3 presents the data and methodology. Finally, Section 4 concludes the paper.

\section{Extant Literature}

Walter Bagehot (1873) and Joseph Schumpeter (1911) are the pioneering scholastic investigation on the significance of the financial system on the economic growth. They opined the central role of the financial system in the economic growth of the economy (Levine 1997). The extant literature on linkage between financial development and economic growth can be classified into multiple categories. In one of the prime study conducted by Patrick (1966), the literature on the purported theme got bifurcated into two categories: firstly the studies that highlight the influence of financial development in stimulating the economic growth, marked as supply leading hypothesis or the finance led growth hypothesis. The supply leading hypotheses reveals that aggressive activities of financial system shall lead to increase in the economic growth. Relatedly, empirical evidence by Goldsmith ( 1969), Hicks (1969),McKinnon (1973), Shaw (1973), King and Levine (1993), Levine (1997), Rajan and Zingales (1998), Darrat, (1999), Hussain and Chakraborty (2012), Nasir, N. M., Ali, N., \& Khokhar, I. (2014) mostly found the financial development as a central input for economic growth and thereby these studies advocate for the supply leading hypothesis. On the contrary, the second sets of studies undermine the purpose of financial development in stimulating the economic growth. These set of studies are christened as demand following hypothesis or the growth -led finance hypothesis. In this second view, it is considered that the economic growth propel the financial development in the country. Studies such as Robinson (1952), Kuznets (1955), Friedman \& Schwarts (1963), Lucas (1988), Odhiambo (2004), Odhiambo (2008), Odhiambo (2009a), Odhiambo (2009b) reveal the role of economic growth in the financial development. The third set of studies pertains to two way causal relationship between finance development and economic growth. Lewis (1955), Patrick (1966), Wood (1993), Dematriades and Hussain (1996), Yucel (2009), Luintel and Khan (1999), Odhiambo (2011) document a bi-directional causality between financial development and economic growth. Additionally, another set of studies reveals that there is no relationship between financial development and economic growth (Ram, 1999). Further there are investigations that reveal that financial development and economic growth has probable negative linkages (De Gregorio and Guidotti, 1995; Al-Malkawi, H. A. N., Marashdeh, H. A., \& Abdullah, N., 2012).

An endeavor is made to review selected studies highlighting on the financial development and economic growth in the Middle East and North Africa (MENA) and in Gulf Cooperation Council (GCC) countries including Bahrain. Kar, M., Nazlioglu, S., \& Agır, H. (2011) examined the direction of causality between financial development and economic growth in the Middle East and North African (MENA) countries. The study applied unrelated regressions and wald tests with the country specific bootstrap critical values, to the panel of fifteen MENA countries for the time span 1980-200.The study report inexplicit understanding on the linkage between financial development and economic growth. Abu-Bader, S., \& Abu-Qarn, A. S. (2008) investigated the causal relationship between financial development and economic growth for six MENA countries enclosed by quadvariate vector autoregressive framework. Through the employment of four distinct scale of financial development and of the augmented vector autoregression vector (VAR) methodology, the study substantially endorse the view that finance stimulate growth in five out of the six countries. Kandil, M. (2006) reveals that monetary policy act as central driver of economic growth in the MENA countries. The study conveys a set of strategies to uplift the financial development in the MENA countries through stimulating the competition in financial sector, fortifying supervision and escalating the ambit of central banks. Boulila, G., \& Trabelsi, M. (2004) explored the financial activity and economic growth for sixteen countries in the MENA region, beginning from 1960 to 2002. Through the employment of multiple tools, the study 
undermine the view that finance deployment promote the growth process in the region. The study reports that Bahrain reveals the causation to be bi-directional.

Naceur, S. B., Cherif, M., \& Kandil, M. (2014) highlights the significance of financial system as a vital ingredient of sustaining growth in the MENA region. The study throws light on the determinants of financial development in the MENA region. DuaSa, J. (2014) examined the influence of financial development on economic growth on selected OIC countries including Bahrain. The study covered the data from 1960-2005 for each country. Utilizing the Vector Autoregressive model (VAR) and Vector Error Correction Model (VECM), the study shows that Bahrain manifest unclear Granger-causality relationship between the financial development and economic growth.

Altaee, H. H. A., \& Al-Jafari, M. K. (2014) explored the linkage between trade openness, financial development and economic growth for the Kingdom of Bahrain. The study covered the time series data from 1980 till 2012.The study report that trade openness and financial development have causal influence on economic growth. Contrarily, growth is revealed to have no causal impact on trade and financial development, thereby endorsing for "trade-led growth" and "finance-led growth". The study recommends that the expansion and development of financial arena shall enhance the economic growth. Abduh, M., Brahim, S., \& Omar, M. A. (2012) investigated the short run and the long run relationships between the paired Islamic and conventional financial development with the economic growth in the Bahrain. Applying the Johansen \& Juselius cointegration test and Vector Error Correction Model (VECM), the study reveals that the conventional finance has a significant short run and long run relationship with the economic growth in the Bahrain economy. Al-Malkawi, H. A. N., Marashdeh, H. A., \& Abdullah, N. (2012) investigated the linkage between financial development and economic growth of United Arab Emirates (UAE).The study covers for the period 1974 to 2008.Utilising the autoregressive distributed lag (ARDL) approach to co-integration, the study exhibits neither the demand-following nor the supply-leading hypothesis for UAE.

Going through the existing literature, it is revealed that multiple econometric tools have been applied to thread bare examine the linkage of financial development and economic growth. Mercan \& Gocer (2013) have concentrated on the panel data analysis. Al-Malkawi et al. (2012) employed the Autoregressive distributed lag (ARDL) bound testing approach in the studies. Jeanneney, S. G., Hua, P., \& Liang, Z. (2006) has applied generalized method of moments. Perera \&Paudel (2009) and Iyare \& Moore (2011) utilised Johansen co-integration and Granger causality tests. Wong \& Zhou (2010) made use of panel regression. King \& Levine (1993) and Levine \& Zervos (1998) applied contemporaneous regressions, sensitivity analyses and Panel data analysis. Abu-Bader \& Abu-Qarn (2008) applied augmented vector autoregression and model. Levine, R., Loayza, N., \& Beck, T. (2000) applied cross-sectional analyses and dynamic panel techniques. Vector autoregression (VAR) and Vector error correction model was applied by Rousseau and Wachtel (1998). Wood (1993) applied lag-length parameterization of the time series Cross-sectionally heteroscedastic and time-wise autoregressive model was applied by Ahmed and Ansari (1998). Tri-variate causality model was applied by Odhiambo (2008).

The extant literature reveals that numerous studies have applied a bi-variate model to investigate the casual relationship between the financial development and economic growth. However, it is, of late, revealed cogently that outcome of the purported test on the financial development and economic growth may be unreasonable on account of exclusion of an significant factor influencing both the stipulated factors (Lutkepohl, 1982).Some of the factors that are predicated to be significant in the finance -growth linkage, encompasses, namely, level of openness, savings, investment and inflation(Odhiambo,2008).In the same vein, the current paper includes savings as an intermitting variable that can affect both the financial development and the economic growth (Odhiambo, 2008). The current study uses a tri-variate causality framework to investigate the causality between financial development, savings and economic growth in Bahrain.

The selection of savings as an intermittent variable has been dominated on account of empirical linkage between financial development \& savings from one point of view, and economic growth \& savings from the other point of view (Odhiambo, 2008). The linkage between economic growth and savings vis-à-vis financial development and savings has been investigated by multiple studies. Studies have revealed favorable linkages between financial sector development and savings (Baliamoune \& Chowdhury, 2003; Kelly \& Mavrotas 2003). Studies reveal that enhancement in savings yield a higher rate of growth on account of its favorable influence on investment and capital accumulation. (Lucas, 1988, Romer, 1986). The Harrod-Domar model of growth anticipates that savings plays a vital factor of growth (Domar, 1946 and Harrod, 1939). Singh, T. (2010) reveals the significant long-run effects of savings on income and the bidirectional causality between savings and growth in Indian economy. Likewise, multiple studies have investigated the relationship between financial development and savings. A formal financial system is anticipated to augment savings by the efficacy in the financial intermediaries (McKinnon 1973; Shaw 1973; 
Jha, S., Prasad, E., Hagiwara, A.T., 2009; Mavrotas, 2008). The current study makes an endeavor to enhance the extant literature by yielding empirics on the linkage between the financial development, savings and the economic growth in Bahrain.

\section{Data and Methodology}

The paper makes earnest investigation to gauge the long run and short run relationship between, financial development, economic growth and the savings. Time series data are taken for a time span of 33 years (1981 - 2013). Data are culled from the World Bank Database. Financial Development measured by M2(broad money)/ GDP is represented by F, Economic growth measured by GDP per capita is represented by $\mathrm{Y}$ and Savings is measured by Domestic Savings/GDP is represented by $\mathrm{S}$.

\subsection{ADF Test of Unit Root}

In order to identify the stationary trend of a time series data, the Augmented Dickey-Fuller (ADF) test is frequently used by the researchers. It is very important to apply these tests to validate the results as non-stationary data nullify the normal statistical tests. This research has applied unit root tests for data to observe the integrated order.

Following is the basic equation of $\mathrm{ADF}$ when we consider a constant and trend.

$$
\Delta \mathrm{X}_{\mathrm{t}=} \lambda_{0}+\lambda_{1 \mathrm{t}}+\lambda_{2} \mathrm{X}_{\mathrm{t}-1}+\sum_{i=1}^{n-1} \lambda i \Delta \mathrm{X}_{\mathrm{t}-1}+\mathrm{E}_{\mathrm{t}}
$$

The Equation above represents a macroeconomic variable in the form of $\Delta \mathrm{X}_{\mathrm{t}}$ in a time period t, while $\lambda_{0}$ is a constant term and $\Delta \mathrm{X}_{\mathrm{t}}=\mathrm{X}_{\mathrm{t}}-\mathrm{X}_{\mathrm{t}-1}$ where $\mathrm{t}$ is a trend variable and $\mathrm{E}_{\mathrm{t}}$ is noise error term in the model.

For the above mentioned equation the Null hypothesis and Alternative hypothesis are as under,

$\mathrm{H}_{0}: \lambda_{2}=0$ (Time series data is Non Stationary)

$\mathrm{H}_{1}: \lambda_{2}<0$ (Time series data is Stationary)

The null hypothesis $\mathrm{H}_{0}$ states that data has a unit root $\mathrm{o}$ and alternative hypothesis $\mathrm{H}_{1}$ states that data do not contain a unit root. Researchers use these unit root tests to calculate t-statistic and probability to compare it with critical values at levels and at the first difference with constant or with constant and trend. If the outcomes confirm that critical values are more than test value at levels we cannot reject $\mathrm{H}_{0}$ that means the data is non stationary. At the first difference if the t-values are greater than the critical values we can reject $\mathrm{H}_{0}$ that means the data is stationary.

\subsection{Phillips-Perron (PP) Test}

Another famous research to establish the integrated order of the data is Phillips and Perron (1988) test for non-parametric unit root. This test is more sophisticated in a way that it also considers the issues of serial correlation and heteroscedasticity in the data. The equation for this test is given below

$$
\Delta \mathrm{Z}_{\mathrm{t}}=\theta \mathrm{Z}_{\mathrm{t}-1}+\alpha+\mathrm{e}_{\mathrm{t}}
$$

Where $\Delta$ indicates the first difference operator in the equation.

The hypothesis established for ADF is same for PP test.

Following Tables 1 and 2 show the results of unit root tests stating that null hypothesis of no unit root cannot be rejected at levels as the values of $t$ statistic is less than the critical values in both tests. That is not the same at first difference where the $t$ values are more than the critical values means $\mathrm{H}_{0}$ is rejected at the first difference. Therefore it can be concluded that all the variables under consideration are non-stationary at level and stationary at first difference.

Table 1. ADF test

\begin{tabular}{lllllllll}
\hline Variables & \multicolumn{2}{l}{ At level } & \multicolumn{3}{c}{ At first difference } \\
\cline { 2 - 9 } & \multicolumn{2}{l}{ With constant } & \multicolumn{2}{l}{$\begin{array}{l}\text { With constant and } \\
\text { linear trend }\end{array}$} & With constant & \multicolumn{2}{l}{$\begin{array}{l}\text { With constant and } \\
\text { linear trend }\end{array}$} \\
\cline { 2 - 9 } & t-stat & C-VALUE & t-stat & C-VALUE & t-stat & C-VALUE & t-stat & C- VALUE \\
\hline Y & 0.92275 & -3.646 & -1.428 & -4.205 & -5.539 & -3.653 & -6.163 & -4.2732 \\
\hline $\mathbf{F}$ & -3.4377 & -3.646 & -3.734 & -4.205 & -8.565 & -3.653 & -8.426 & -4.2732 \\
\hline $\mathbf{S}$ & -1.7545 & -3.646 & -1.909 & -4.205 & -5.442 & -3.653 & -5.626 & -4.2732 \\
\hline
\end{tabular}


Table 2. PP test

\begin{tabular}{lllllllll}
\hline VARIABLES & \multicolumn{1}{l}{ At level } & \multicolumn{5}{l}{ At first difference } \\
\cline { 2 - 9 } & \multicolumn{1}{l}{ With trend } & \multicolumn{2}{l}{$\begin{array}{l}\text { With trend and } \\
\text { intercept }\end{array}$} & With trend & With trend and intercept \\
\cline { 2 - 9 } & t-stat & $\begin{array}{l}\text { C- } \\
\text { VALUE }\end{array}$ & $\begin{array}{l}\text { t-stat } \\
\text { C- } \\
\text { VALUE }\end{array}$ & t-stat & C-VALUE & t-stat & C- VALUE \\
\hline $\mathrm{Y}$ & 1.054 & -3.646 & -1.265 & -4.205 & -5.536 & -3.653 & -6.515 & -4.2732 \\
\hline $\mathrm{F}$ & -3.437 & -3.646 & -3.734 & -4.205 & -8.688 & -3.653 & -8.565 & -4.2732 \\
\hline $\mathrm{S}$ & -1.7862 & -3.646 & -1.861 & -4.205 & -5.438 & -3.653 & -5.737 & -4.2732 \\
\hline
\end{tabular}

\subsection{Johansen Test for Co-integration}

After addressing the issue of unit root, the co-integration test can be applied in order to establish the long run relationship among the variables. The co-integration theory describes that although the variables in a model are non-stationary at levels but the linear relationship among them may still be stationary at difference. This specific work has applied multivariate co-integration approach which was developed by Johansen and Juselius (1990) to establish that relationship.

Table 3 below displays the results of Johansen co-integration test. As it can be seen from the outcomes, there is no co-integrated equation. This means the absence of any long run relationship among the variables under consideration. Trace test and Max-Eigen values are lower than the critical values and p- values for them are also insignificant which asserts that Vector Error Correction Model (VECM) is not applicable in this specific case.

Table 3. Johansen co-integration test

Unrestricted Cointegration Rank Test (Trace)

\begin{tabular}{|c|c|c|c|c|c|c|c|c|c|}
\hline Hypothesized & & Trace & 0.05 & & Hypothesized & & Max-Eigen & 0.05 & \\
\hline & Eigen & & Critical & & & Eigen & & Critical & \\
\hline No. of CE(s) & value & Statistic & Value & Prob.** & No. of $\mathrm{CE}(\mathrm{s})$ & value & Statistic & Value & Prob.** \\
\hline None & 0.401493 & 23.15148 & 29.79707 & 0.2387 & None & 0.401493 & 16.42613 & 21.13162 & 0.2009 \\
\hline At most 1 & 0.179028 & 6.725343 & 15.49471 & 0.6098 & At most 1 & 0.179028 & 6.312512 & 14.26460 & 0.5735 \\
\hline At most 2 & 0.012818 & 0.412831 & 3.841466 & 0.5205 & At most 2 & 0.012818 & 0.412831 & 3.841466 & 0.5205 \\
\hline
\end{tabular}

Trace test indicates no cointegration at the 0.05 level

* denotes rejection of the hypothesis at the 0.05 level

**MacKinnon-Haug-Michelis (1999) p-values

\subsection{Unrestricted Vector Auto-regression (VAR)}

Vector auto regression (VAR) is a model in econometrics which is used to understand the linear relationships for variables with multiple time series. It simplifies the autoregressive models by permitting the effect for more than one changing variable on relevant time series data under consideration. The model in a VAR treats all variables as endogenous so separate equation is generated for each variable. Every equation in VAR consists of lagged values of all the variables as independent variables including the dependent variable itself. The basic equations used for VAR in the reduced form are given below:

$$
\begin{aligned}
& \mathrm{Y}_{\mathrm{t}, 1}=\alpha_{1}+\varphi_{11} \mathrm{Y}_{\mathrm{t}-1,1}+\varphi_{12} \mathrm{~F}_{\mathrm{t}-1,2}+\varphi_{13} \mathrm{~S}_{\mathrm{t}-1,3}+\mathrm{w}_{\mathrm{t}, 1} \\
& \mathrm{~F}_{\mathrm{t}, 2}=\alpha_{2}+\varphi_{21} \mathrm{Y}_{\mathrm{t}-1,1}+\varphi_{22} \mathrm{~F}_{\mathrm{t}-1,2}+\varphi_{23} \mathrm{~S}_{\mathrm{t}-1,3}+\mathrm{w}_{\mathrm{t}, 2} \\
& \mathrm{~S}_{\mathrm{t}, 3}=\alpha_{3}+\varphi_{31} \mathrm{Y}_{-1,1}+\varphi_{32} \mathrm{~F}_{\mathrm{t}-1,2}+\varphi_{33} \mathrm{~S}_{\mathrm{t}-1,3}+\mathrm{w}_{\mathrm{t}, 3}
\end{aligned}
$$


The Table 4 depicts the results of VAR in which one can examine some significant values of coefficients that establish there may exist a relationship among the variables. The values of coefficients of GDP represented by $\mathrm{Y}$ with lag 1 significantly affect GDP and economic growth while the value of intercept in the equation is not much significant, where financial development represented by $\mathrm{F}$ and savings represented by $\mathrm{S}$ has no significant effects on the GDP. If we consider Financial development as a dependent variable, the lagged GDP and Financial development have significant coefficient values while savings does not affect the financial development in that equation while intercept is also significant. If the savings is taken as dependent variable the coefficients of $\mathrm{Y}$ and $\mathrm{S}$ are significant while the constant is same, the $\mathrm{F}$ has no significance in this equation.

Following are the three equations with the substituted values of the related coefficients in the above mentioned equations after generating the VAR results.

$$
\begin{aligned}
& \mathrm{Y}=1.034085 * \mathrm{Y}(-1)+0.000402 * \mathrm{~F}(-1)+-0.000727 * \mathrm{~S}(-1)--0.109087 \\
& \mathrm{~F}=12.25702 * \mathrm{Y}(-1)+0.442633 * \mathrm{~F}(-1)+-0.050215 * \mathrm{~S}(-1)-4.919872 \\
& \mathrm{~S}=11.24709 * \mathrm{Y}(-1)-0.009177 * \mathrm{~F}(-1)+0.778804 * \mathrm{~S}(-1)+-32.11282
\end{aligned}
$$

Table 4. Vector auto regression estimates

Vector Autoregression Estimates

Sample (adjusted): 19812013

Included observations: 33 after adjustments

Standard errors in ( ) \& t-statistics in [ ]

\begin{tabular}{cccc}
\hline & $\mathrm{Y}$ & $\mathrm{F}$ & $\mathrm{S}$ \\
\hline $\mathrm{Y}(-1)$ & 1.034085 & 12.25702 & 11.24709 \\
\hline & $(0.04916)$ & $(11.0343)$ & $(7.14395)$ \\
\hline $\mathrm{F}(-1)$ & {$[21.0366]$} & {$[1.11081]$} & {$[1.57435]$} \\
\hline & 0.000402 & 0.442633 & -0.009177 \\
\hline & $(0.00073)$ & $(0.16416)$ & $(0.10628)$ \\
\hline $\mathrm{S}(-1)$ & {$[0.54997]$} & {$[2.69629]$} & {$[-0.08634]$} \\
\hline & -0.000727 & -0.050215 & 0.778804 \\
\hline $\mathrm{C}$ & $(0.00070)$ & $(0.15814)$ & $(0.10238)$ \\
\hline & {$[-1.03187]$} & {$[-0.31754]$} & {$[7.60671]$} \\
\hline & -0.109087 & -4.919872 & -32.11282 \\
\hline R-squared & $(0.15891)$ & $(35.6716)$ & $(23.0949)$ \\
\hline Adj. R-squared & {$[-0.68646]$} & {$[-0.13792]$} & {$[-1.39047]$} \\
\hline F-statistic & 0.953889 & 0.301573 & 0.777590 \\
\hline \hline & 0.949119 & 0.229322 & 0.754582 \\
\hline \hline
\end{tabular}

\section{The selection of lag length:}

As the VAR model is responsive to lag lengths, so the research has applied lag length selection criteria to obtain the best lag length for the model. The outcomes of different selection methods are given in the Table5, which shows that the optimal lag for the model is lag order 1 which is recommended by all of the selection criteria.

Table 5. Lag selection criteria

\begin{tabular}{ccccccc}
\hline Lag & LogL & LR & FPE & AIC & SC & HQ \\
\hline \hline 0 & -204.2971 & NA & 129.0811 & 13.37400 & 13.51278 & 13.41924 \\
\hline 1 & -119.8238 & $147.1469^{*}$ & $0.995483^{*}$ & $8.504764^{*}$ & $9.059855^{*}$ & $8.685710^{*}$ \\
\hline 2 & -112.1007 & 11.95840 & 1.102157 & 8.587142 & 9.558553 & 8.903798 \\
\hline 3 & -106.6623 & 7.368152 & 1.454928 & 8.816923 & 10.20465 & 9.269288 \\
\hline
\end{tabular}

* indicates lag order selected by the criterion 
LR: sequential modified LR test statistic (each test at 5\% level)

FPE: Final prediction error

AIC: Akaike information criterion

SC: Schwarz information criterion

HQ: Hannan-Quinn information criterion

\subsection{Granger Causality Test}

As the VAR does not interpret the direction of causality so the researchers have also used the granger causality to identify the Causal relationship. The Granger Causality test is widely used test in the literature to establish the causal relationship among the variables. Granger Causality can be described with the help of following equations.

$$
\begin{aligned}
& \mathrm{Y}_{\mathrm{t}}=\alpha_{0}+\sum_{\mathrm{i}=1}^{\mathrm{m}} \alpha_{1 \mathrm{i}} \mathrm{Y}_{\mathrm{t}-\mathrm{i}}+\sum_{\mathrm{i}=1}^{\mathrm{n}} \alpha_{2 \mathrm{i}} \mathrm{F}_{\mathrm{t}-\mathrm{i}}+\sum_{\mathrm{i}=1}^{\mathrm{n}} \alpha_{3 \mathrm{i}} \mathrm{S}_{\mathrm{t}-\mathrm{i}}+\alpha_{4} \mathrm{ECT}_{\mathrm{t}-1}+\emptyset_{\mathrm{t}} \\
& \mathrm{S}_{\mathrm{t}}=\beta_{0}+\sum_{\mathrm{i}=1}^{\mathrm{m}} \beta_{1 \mathrm{i}} \mathrm{Y}_{\mathrm{t}-\mathrm{i}}+\sum_{\mathrm{i}=1}^{\mathrm{n}} \beta_{2 \mathrm{i}} \mathrm{F}_{\mathrm{t}-\mathrm{i}}+\sum_{\mathrm{i}=1}^{\mathrm{n}} \alpha_{3 \mathrm{i}} \mathrm{S}_{\mathrm{t}-\mathrm{i}}+\beta_{4} \mathrm{ECT}_{\mathrm{t}-1}+\theta_{\mathrm{t}} \\
& \mathrm{F}_{\mathrm{t}}=\psi_{0}+\sum_{\mathrm{i}=1}^{\mathrm{m}} \psi_{1 \mathrm{i}} \mathrm{Y}_{\mathrm{t}-\mathrm{i}}+\sum_{\mathrm{i}=1}^{\mathrm{n}} \Psi_{2 \mathrm{i}} \mathrm{F}_{\mathrm{t}-\mathrm{i}}+\sum_{\mathrm{i}=1}^{\mathrm{n}} \Psi_{3 \mathrm{i}} \mathrm{S}_{\mathrm{t}-\mathrm{i}}+\psi_{4} \mathrm{ECT}_{\mathrm{t}-1}+\Pi_{\mathrm{t}}
\end{aligned}
$$

In the above mentioned model, GDP is represented by $\mathrm{Y}, \mathrm{F}$ is the financial development and $\mathrm{S}$ is the savings while $\mathrm{ECT}_{\mathrm{t}-\mathrm{l}}$ is error correction term at lag length one and remaining $\emptyset, \theta$ and $\Pi$ are white noise residual and $\alpha_{0}, \beta_{0}, \psi_{0}$ are the respective intercepts.

The results of granger causality test depicts few causal relationships .The savings have bi- directional relationship with GDP where both can cause each other at $10 \%$ level of significance. This is also true for savings and economic growth where both variables are causing each other as well. There is no other significant directional relationship that can be established among the given variables.

Table 6. VAR Granger Causality/Block Erogeneity Wald Tests

Pairwise Granger Causality Tests

Sample: $1981-2013$

Lags: 1

\begin{tabular}{lccc}
\hline Null Hypothesis: & Obs & F-Statistic & Prob. \\
\hline F does not Granger Cause Y & 33 & 1.06287 & 0.3108 \\
\hline Y does not Granger Cause F & & 1.24892 & 0.2726 \\
\hline S does not Granger Cause Y & 33 & 1.87094 & 0.0813 \\
\hline Y does not Granger Cause S & & 2.81986 & 0.0935 \\
\hline S does not Granger Cause F & 33 & 0.07781 & 0.7822 \\
\hline F does not Granger Cause S & & 0.24344 & 0.6253 \\
\hline
\end{tabular}

\subsection{The Impulse Response Function}

After the above mentioned tests impulse response function was utilized to determine the impact of shock to the given variables. Impulse response function illustrates the effect of a one-time shock to one of the variations on current and future values of all the endogenous variables taken in a model. This shock also transfers its impact to all other endogenous variables via the lag structure of the VAR in a model beside itself. This specific work has utilized the $3 \times 3$ graphs in order to depict the outcomes of impulse response on each variable. 
The graphs show how the $\mathrm{Y}$ or economic growth respond to a shock to the all the variables under consideration including itself, Financial development and savings. The response of a shock too, is both positive and negative at times. The effect of shock for financial development to itself and savings and economic growth is stable while it's generally negative in case of savings. For a shock to savings the response to itself and GDP is negative.

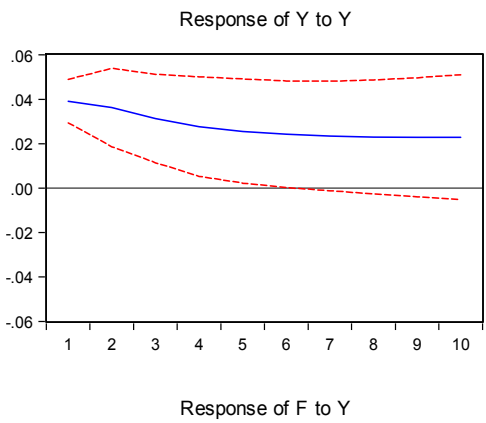

Response to Cholesky One S.D. Innovations \pm 2 S.E.
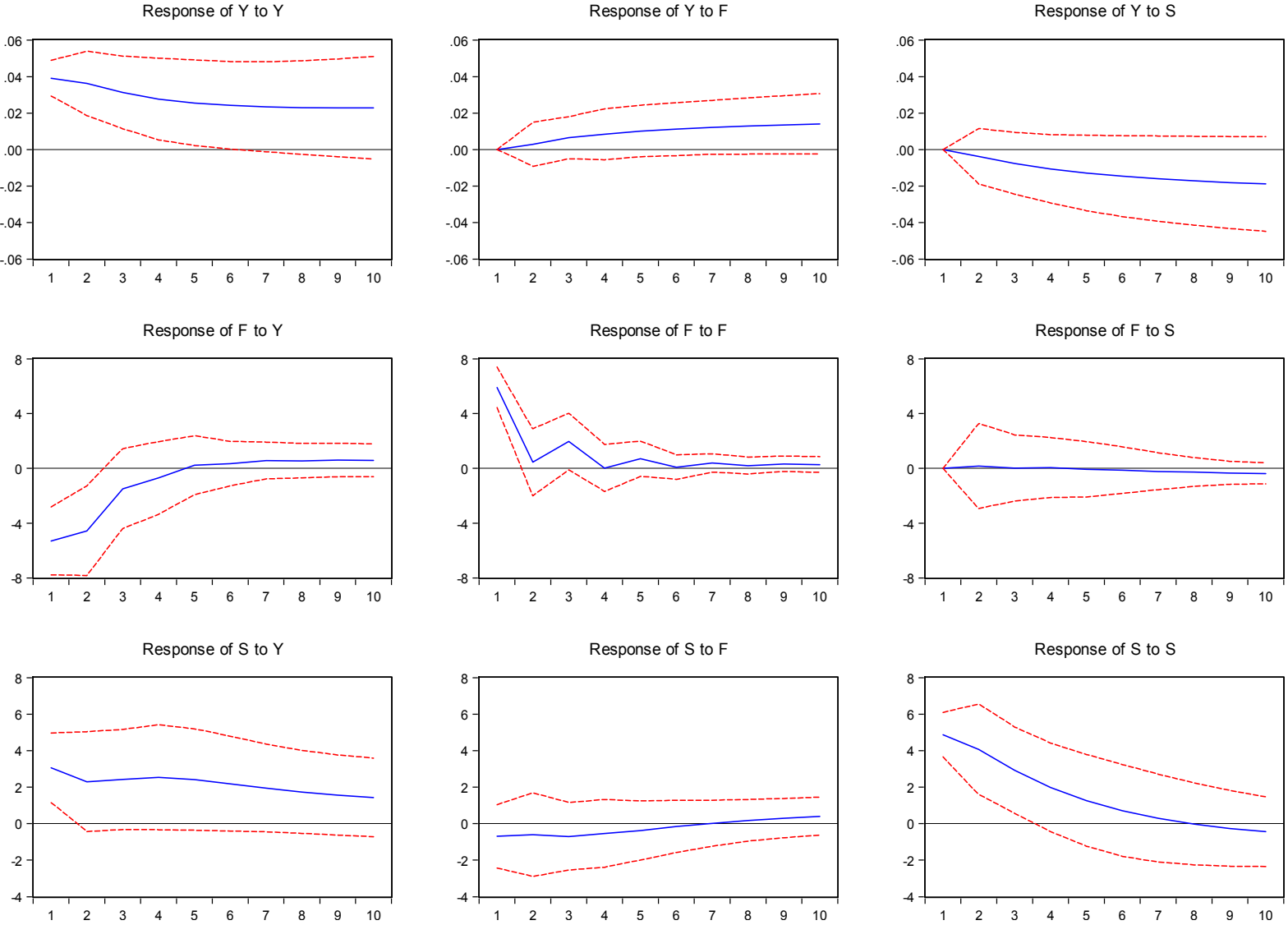

\subsection{Variance Decomposition Method}

In order to depict the system dynamics, Variance decomposition is another appropriate technique. As it is a feature of impulse response functions to show the effects of a shock to endogenous variable on the variables in the model, Variance Decomposition Method decomposes the variation in an endogenous variable into the component shocks with respect to other variables in the model. It is of importance nature as it gives the information about specific random innovations to the variables in the system.

Tables 7, 8 \& 9. Variance decomposition of $\mathrm{Y}, \mathrm{F}$ and $\mathrm{S}$

\begin{tabular}{ccccc}
\hline Period & S.E. & Y & F & S \\
\hline 1 & 0.037695 & 100.0000 & 0.000000 & 0.000000 \\
\hline 2 & 0.051731 & 99.17614 & 0.395262 & 0.428596 \\
\hline 3 & 0.062252 & 97.78753 & 0.913771 & 1.298697 \\
\hline 4 & 0.071169 & 96.13376 & 1.410394 & 2.455849 \\
\hline 5 & 0.079160 & 94.38054 & 1.849659 & 3.769805 \\
\hline 6 & 0.086537 & 92.62546 & 2.229619 & 5.144922 \\
\hline
\end{tabular}




\begin{tabular}{ccccc}
\hline 7 & 0.093470 & 90.92632 & 2.557130 & 6.516548 \\
\hline 8 & 0.100058 & 89.31585 & 2.840270 & 7.843879 \\
\hline 9 & 0.106365 & 87.81059 & 3.086278 & 9.103136 \\
\hline 10 & 0.112437 & 86.41669 & 3.301183 & 10.28213 \\
\hline
\end{tabular}

\begin{tabular}{ccccc}
\hline Period & S.E. & $\mathrm{Y}$ & $\mathrm{F}$ & $\mathrm{S}$ \\
\hline \hline & & & & \\
\hline 1 & 8.461580 & 28.01841 & 71.98159 & 0.000000 \\
\hline 2 & 9.202005 & 26.95694 & 72.97843 & 0.064632 \\
\hline 3 & 9.336458 & 26.40825 & 73.40611 & 0.185643 \\
\hline 4 & 9.372688 & 26.21434 & 73.45282 & 0.332848 \\
\hline 5 & 9.394685 & 26.21299 & 73.29963 & 0.487374 \\
\hline 6 & 9.415774 & 26.30577 & 73.05331 & 0.640912 \\
\hline 7 & 9.437475 & 26.44316 & 72.76617 & 0.790665 \\
\hline 8 & 9.459659 & 26.60200 & 72.46186 & 0.936144 \\
\hline 9 & 9.482132 & 26.77168 & 72.15063 & 1.077691 \\
\hline 10 & 9.504794 & 26.94732 & 71.83680 & 1.215883 \\
\hline
\end{tabular}

\begin{tabular}{ccccc}
\hline Period & S.E. & Y & F & S \\
\hline 1 & 5.478289 & 26.84012 & 0.839317 & 72.32057 \\
\hline 2 & 7.109349 & 30.09945 & 0.911140 & 68.98941 \\
\hline 3 & 8.041552 & 33.14293 & 0.899989 & 65.95708 \\
\hline 4 & 8.634779 & 35.99716 & 0.850895 & 63.15195 \\
\hline 5 & 9.039649 & 38.65867 & 0.793293 & 60.54804 \\
\hline 6 & 9.334705 & 41.11427 & 0.744410 & 58.14132 \\
\hline 7 & 9.564833 & 43.35221 & 0.713233 & 55.93455 \\
\hline 8 & 9.756797 & 45.36742 & 0.703453 & 53.92913 \\
\hline 9 & 9.926837 & 47.16275 & 0.715472 & 52.12177 \\
\hline 10 & 10.08484 & 48.74822 & 0.747761 & 50.50402 \\
\hline & & & &
\end{tabular}

From the results in Tables 7, 8 and 9 above, it can be demonstrated that almost 3 per cent of GDP can be explained by the effects of savings while it is about 10 per cent for financial development. At the other hand 27 per cent of the financial development can be explained by the variations in GDP, while it is only 1.2 per cent with respect to effect of savings on financial development. Savings are determined up to 48 per cent by the effects of GDP and it is only 0.74 per cent in the case of financial development which is negligible. The above mentioned results substantiate the outcomes of impulse response function.

\section{Conclusion}

This study was undertaken to investigate the existence of the relationship among financial development, savings and economic growth in Bahrain for which the study applied tri-variate casualty model. The data consisted of 33 years ranging from 1981 to 2013. The data was taken from the World Bank database to ensure its reliability. As the results of Johansen co-integration report, the study is not able to establish any long term relationship among the variables. Further, Vector Autoregressive Model is used to investigate this relationship. The outcome discloses the existence of 
relationship between economic growth and savings. The results of Granger also reveal bi-directional causality between economic growth and savings at 10 percent level of significance which manifests that savings and economic growth cause each other in Bahrain. There is no causality between financial development and savings, like-wise is evinced for financial development and economic growth which is in sync with the previous studies conducted on the purported theme. The research further uses the impulse response function and variance decompositions to ascertain the impact of any change or shocks on the variables under consideration. The results of these tests exhibit that almost 3 per cent of GDP can be explained by the effects of savings, while it is about 10 per cent for financial development. On the other hand, 27 per cent of the financial development can be explained by the variations in GDP, while it is only 1.2 per cent with respect to effect of savings on financial development. Savings are determined up to 48 per cent by the effects of GDP and it is only 0.74 per cent in the case of financial development which is negligible. The above mentioned results substantiate the outcomes of impulse response function.

On the whole, the empirical evidence supports neither the supply -leading hypothesis nor the demand -following hypothesis for the Bahrain. In responding to inexplicit result between the purported variables, the current study recommends that more wide ranges of reforms in the financial services are entailed, so as to spur the economic growth in the Bahrain economy. Overall results disclose that savings is an important component to consider which effects economic growth in the country. More advanced proxies for financial development are not being incorporated in this study due to paucity of time series data. Future research should make comparative studies of various GCC countries that encompass more variables, namely, FDI, capital formation and stock market performance.

\section{Acknowledgment}

The authors would like to thank the Deanship of Scientific Research at King Saud University represented by the Research Center at CBA for supporting this research financially.

\section{References}

Abduh, M., Brahim, S., \& Omar, M. A. (2012). A study on finance-growth nexus in dual financial system countries: Evidence from Bahrain. World Applied Sciences Journal, 20(8), 1166-1174.

Abu-Bader, S., \& Abu-Qarn, A. S. (2008). Financial development and economic growth: Empirical evidence from Six MENA countries. Review of Development Economics, 12(4), 803-817 http://dx.doi.org/10.1111/j.1467-9361.2008.00427.x

Ahmed, S. M., \& Ansari, M. I. (1998). Financial sector development and economic growth: the South-Asian experience. Journal of Asian Economics, 9(3), pp. 503-517. http://dx.doi.org/10.1016/S1049-0078(99)80100-6

Al Qassim, A.R. (2013). Financial services in Bahrain will continue to play an active role in the national development. The Bahrain Banker, Bahrain Association of Banks. Bahrain.

Al-Malkawi, H. A. N., Marashdeh, H. A., \& Abdullah, N. (2012). Financial development and economic growth in the UAE: Empirical assessment using ARDL approach to co-integration. International Journal of Economics and Finance, 4(5), 105-115. http://dx.doi.org/10.5539/ijef.v4n5p 105

Altaee, H. H. A., \& Al-Jafari, M. K. (2014). Financial Development, Trade Openness and Economic Growth: A Trilateral Analysis of Bahrain. International Journal of Economics and Finance, 7(1), 241. http://dx.doi.org/10.5539/ijef.v7n1p241

Bagehot, W. (1873). Lombart street: A Description of the money market. New York, Wiley \& Sons

Baliamoune-Lutz, M., \& Chowdhury, A. (2003, March 1). The Long-Run Behavior and Short-Run Dynamics of Private Savings in Morocco. Savings and Development, 27(2), 135-160.

Boulila, G., \& Trabelsi, M. (2004). The causality issue in the finance and growth nexus: empirical evidence from Middle East and North African countries. Review of Middle East Economics and Finance, 2(2), 123-138. http://dx.doi.org/10.1080/1475368042000262820

Darrat, A. F. (1999). Are financial deepening and economic growth casually related? Another look at the evidence. International Economic Journal, 13, 19-35.

De Gregorio, J., \& Guidotti, P. (1995). Financial development and economic growth. World Development, 23, 433-448. http://dx.doi.org/10.1016/0305-750X(94)00132-I

Dematriades, P. O., \& Hussain, K. A. (1996). Does financial development cause economic growth? Time series evidence from 16 countries. Journal of Development Economics, 51, 387-411. http://dx.doi.org/10.1016/S0304-3878(96)00421-X 
Domar, E. D. (1946). Capital expansion, rate of growth, and employment. Econometrica, Journal of the Econometric Society, 137-147. http://dx.doi.org/10.2307/1905364

DuaSa, J. (2014). Financial Development and Economic Growth: The Experiences of Selected OIC Countries. International Journal of Economics \& Management, 8(1).

Friedman, M., \& Schwartz, A. J. (1963). A Monetary History of the United States. Princeton: PUP

Goldsmith, R. (1969). Financial structure and development (1st ed.). Yale University Press, New Haven, p. 561.

Harrod, R. F. (1939). An essay in dynamic theory. The Economic Journal, 14-33.

Hicks, J. (1969). A theory of economic history. Oxford, Claredon Press.

Hussain, F., \& Chakraborty, D. K. (2012). Causality between financial development and economic growth: evidence from an Indian State. The Romanian Economic Journal, 15(45), 27-48.

Iyare, S., \& Moore, W. (2011). Financial sector development and growth in small open economies. Applied Economics, 43, 1289-1297. http://dx.doi.org/10.1080/00036840802600350

Jeanneney, S. G., Hua, P., \& Liang, Z. (2006). Financial development, economic efficiency, and productivity growth: evidence from China. Developing Economies, 44, 27-52. http://dx.doi.org/10.1111/j.1746-1049.2006.00002

Jha, S., Prasad, E., \& Hagiwara, A. T. (2009). Saving in Asia and Issues for Rebalancing Growth. Asian Development Bank Economic Working Paper, No. 162 (Manila).

Kandil, M. (2006). Financial development and economic growth in the MENA countries. Contributions to Economic Analysis, 278, 104-136.

Kar, M., Nazlıoglu, Ş., \& Agır, H. (2011). Financial development and economic growth nexus in the MENA countries: Bootstrap panel granger causality analysis. Economic Modelling, 28(1), 685-693. http://dx.doi.org/10.1016/j.econmod.2010.05.015

Kelly, R., \& Mavrotas, G. (2003). Savings and Financial Sector Development: Panel Cointegration Evidence from Africa. WIDER Discussion Paper No. 2003/12. Helsinki: UNU-WIDER.

King, R. G., \& Levine, R. (1993). Finance and growth: Schumpeter might be right. Quarterly Journal of Economics, 108(3), 717-737. http://dx.doi.org/10.2307/2118406

Kuznets, S. (1955). Economic growth and income inequality. American Economic Review, 45, 1-28.

Levine, R. (1997). Financial development and economic growth: views and agenda. Journal of Economic Literature. $35,688-726$.

Levine, R., \& Zervos, S. (1998). Stock markets, banks and economic growth. American Economic Review, 88(3), 537-58

Levine, R., Loayza, N., \& Beck, T. (2000). Financial intermediation and growth: Causality and causes. Journal of Monetary Economics, 46, 31-77. http://dx.doi.org/10.1016/S0304-3932(00)00017-9

Lewis, W. A. (1955). The Theory of Economic Growth. George Allen and Unwin, London.

Lucas, R. E. Jr. (1988). On the Mechanics of Economic Development. Journal of Monetary Economics, 22, 3-42. http://dx.doi.org/10.1016/0304-3932(88)90168-7

Luintel, K. B., \& Khan, M. (1999). A quantitative reassessment of the finance-growth nexus: evidence from a multivariate VAR. Journal of Development Economics, 60, 381-405. http://dx.doi.org/10.1016/S0304-3878(99)00045-0

Lutkepohl, H. (1982). Non-causality due to omitted variables. Journal of Econometrics, 19, 367-378. http://dx.doi.org/10.1016/0304-4076(82)90011-2

Mavrotas, G. (2008). Domestic resource mobilization and financial development: introduction. In Mavrotas, George (Ed.), Domestic Resource Mobilization and Financial Development. Palgrave Macmillan, New York. http://dx.doi.org/10.1057/9780230594012

McKinnon, R. I. (1973). Money and Capital in Economic Development. Washington DC: The Brookings Institution.

Mercan, M., \& Göçer, İ. (2013). The effect of financial development on economic growth in BRIC-T countries: Panel data analysis. Journal of Economic and Social Studies, 3(1), 199-216. http://dx.doi.org/10.14706/JECOSS11318 
Naceur, S. B., Cherif, M., \& Kandil, M. (2014). What drives the development of the MENA financial sector?. Borsa Istanbul Review, 14(4), 212-223. http://dx.doi.org/10.1016/j.bir.2014.09.002

Nasir, N. M., Ali, N., \& Khokhar, I. (2014). Economic Growth, Financial Depth and Lending Rate Nexus: A Case of Oil Dependant Economy. International Journal of Financial Research, 5(2), 59. http://dx.doi.org/10.5430/ijfr.v5n2p59

Odhiambo, N. M. (2004). Is financial development still a spur to economic growth? A causal evidence from South Africa. Savings and Development, 28, 47-62.

Odhiambo, N. M. (2008). Financial depth, savings and economic growth in Kenya: a dynamic causal linkage. Economic Modelling, 25, 704-713. http://dx.doi.org/10.1016/j.econmod.2007.10.009

Odhiambo, N. M. (2009a). Finance-growth nexus and inflation dynamics in Kenya: an empirical investigation. Savings and Development, 33(1), 7-25.

Odhiambo, N. M. (2009b). Finance-growth-poverty nexus in South Africa: a dynamic causality linkage. Journal of Socio-Economics, 38, 320-325. http://dx.doi.org/10.1016/j.socec.2008.12.006

Odhiambo, N. M. (2011). Financial intermediaries versus financial markets: a South African experience. International Business and Economics Research Journal, 10(2), 77-84.

Patrick, H. T. (1966). Financial development and economic growth in underdeveloped countries. Economic Development and Cultural Change, 14, 174-89. http://dx.doi.org/10.1086/450153

Perera, N., \& Paudel, R. (2009). Financial development and economic growth in Sri Lanka. Applied Econometrics and International Development, 9(1), 157-164.

Rajan, R. G., \& Zingales, L. (1998). Financial dependence and growth. American economic Review, 88, 559 -86.

Ram, R. (1999). Financial development and economic growth: additional evidence. J. Dev. Stud., 35(4), 164-174. http://dx.doi.org/10.1080/00220389908422585

Retrieved from http://search.proquest.com/docview/1510315432?accountid=142908

Retrieved

from http://www.marketresearch.com/Business-Monitor-International-v304/Bahrain-Business-Forecast-Q1-8538037

Retrieved from http://www.oxfordbusinessgroup.com/bahrain-2012/economy

Retrieved from http://www.oxfordbusinessgroup.com/bahrain-2013/banking

Retrieved from http://www.oxfordbusinessgroup.com/news/steady-growth-bahrain\%E2\%80\%99s-economy

Robinson, J. (1952). The Generalization of the General Theory. In Robinson, The Rate of Interest and Other Essays. London: Macmillan.

Romer, P. M. (1986). Increasing returns and long-run growth. The Journal of Political Economy, 1002-1037. http://dx.doi.org/10.1086/261420

Rousseau, L., \& Wachtel, P. (1998). Financial intermediation and economic performance: historical evidence from five industrialised countries. Journal of Money, Credit and Banking, 30, 657-678. http://dx.doi.org/10.2307/2601123

Schumpeter, J. A. (1911). The Theory of Economic Development. Harvard University Press, Cambridge, MA.

Shaw, E. S. (1973). Financial Deepening and Economic Development. New York: Oxford University Press.

Singh, T. (2010). Does domestic saving cause economic growth? A time-series evidence from India. Journal of Policy Modeling, 32(2), 231-253. http://dx.doi.org/10.1016/j.jpolmod.2009.08.008

Wong, A., \& Zhou, X. (2010). Development of financial market and economic growth: Review of Hong Kong, China, Japan, the United States and the United Kingdom. International Journal of Economics and Finance, 3(2), 111-115.

Wood, A. (1993). Financial development and economic growth in Barbados: Causal evidence. Savings and Development, 17(4), 379-390.

Yucel, F. (2009). Causal Relationships between Financial Development, Trade Openness and Economic Growth: The Case of Turkey. Journal of Social Sciences, 5(1), 33-42. http://dx.doi.org/10.3844/jssp.2009.33.42 